\title{
HIMLEN OVER BEIJING
}

\author{
Undergrundskirker, kinesiske unge og forhandlingen af politiske og \\ eksistentielle grænser
}

SUSANNE BREGNBAK

I 2010 blev Shouwangkirken, en kristen undergrundskirke eller på kinesisk ,huskirke“ (jiating jiahui) ryddet af politiet. Kirkens menighed var på over 1000 personer og fyldte en hel etage af et lejlighedskompleks. Det, der tilsyneladende gjorde udslaget, var imidlertid ikke menighedens størrelse, men at præsten flyttede sin prædiken udenfor og holdt den på en offentlig plads i Haidiandistriktet. Dermed overskred han statens grænser for religiøs udøvelse. Nogle af kirkens medlemmer blev sat $i$ detentionen, og i flere internationale medier kunne man læse om, hvordan $\mathrm{de}$ - iført håndjern - sang salmer i politibilerne hele vejen til politistationen. Herefter blev dørene til kirken låst udefra, så de ikke længere kunne komme ind.

Denne artikel er baseret på mine erfaringer fra feltarbejde i og omkring Det Nye Træs Kirke, en protestantisk undergrundskirke i umiddelbar nærhed af den lukkede kirke. I Kina er kristendom, der har eksisteret i landet siden det syvende århundrede, nu den hurtigst voksende religion (Bautista \& Lim 2009). ${ }^{1}$ Selvom forfatningen fra 1978 i princippet tillader religionsfrihed, kontrolleres religiøse grupperinger af staten. Dette betyder, at det er lovligt at deltage i statskirker, der overvåges af det kommunistiske parti, men disse officielle kirker betragtes af mange kinesere som „falske kirker“ (Vala 2009:96).

Med afsæt i Hannah Arendts tese om, at grænsen imellem den private og den offentlige sfære udgør et politisk forhold (Arendt 1958:50-51), vil jeg analysere, hvad der er på spil for de mange unge kinesere, der konverterer til kristendom og bliver del af de populære undergrundskirker. Grænser forstås i denne artikel både politisk - i forhold til statens direkte og indirekte kontrol - og eksistentielt som et spørgsmål om graden af valgfrihed i egen tilværelse og forholdet til ens nærmeste. På denne baggrund vil jeg spørge til forholdet imellem individuelle biografier og ønsket om at overskride grænserne for det, den kinesiske stat tillader, og til forholdet imellem accept af det givne og ønsket om at overskride rammerne for ens liv. 


\section{Politiske og eksistentielle grænser}

På trods af Mao Zedong-æraen og i særdeleshed Kulturrevolutionens (196676) forsøg på at udslette alle former for religiøsitet har religion siden da langt overskredet de rammer, inden for hvilke Deng Xiaopings Periode for Åbenhed og Reformer tillod en genkomst af religiøsitet (Madsen 1998; Aikman 2003; Scott 2007; Yang 2008; Ashiwa \& Wank 2009). Bogstaveligt talt millioner af templer er blevet bygget eller genopført. Pilgrimme valfarter til buddhistiske templer og daoistiske gravsteder, og kristendommen har haft en eksplosiv vækst.

Da religion fortsat er et følsomt emne for den kinesiske regering, er det så godt som umuligt at finde entydige statistikker over antallet af kristne i Kina (Madsen 2011:18). Ifølge kinesiske officielle statistikker er der 20 millioner kristne i Kina. Ifølge vestlige akademikere er tallet snarere et sted imellem 100 og 130 millioner. ${ }^{2}$ David Aikman, tidligere korrespondent for Time Magazine og forfatter til bogen Jesus in Beijing, ser fremvæksten af kristendom som en del af „Kinas store opvågnen“, der vil være med til at demokratisere Kina, og han går så vidt som til at hævde, at om 30 år vil en tredjedel af Kinas befolkning være kristne (Aikman 2003). Uanset hvad det præcise antal er, udfordrer kristendommen i øjeblikket den kinesiske stats selvbillede og moralske legitimitet. Katolske og protestantiske kirker administreres og overvåges af henholdsvis den Katolske Patriotiske Forening og de Tre Selvers Patriotiske Forening, der begge hører under Kinas Bureau for Religiøse Anliggender.

En del litteratur om fremvæksten af kinesisk kristendom argumenterer for, at kristendommen kan være med til at skabe et civilsamfund i Kina (Madsen 1998; Lozada 2001). Selvom disse studier er værdifulde, mener jeg, at de overlapper med en menneskerettighedsagenda om at udvide religiøse rettigheder i Kina og dermed både overser de særlige kinesiske opfattelser af forholdet imellem religion og stat og måske samtidig en vigtig eksistentiel dimension. Jeg mener dog ikke, at religion primært handler om individets behov for at skabe en mening i sin tilværelse. Derimod vil jeg undersøge unge kineseres tro som forbundet med et ønske om valgfrihed i forhold til autoriteter i form af både forældre og stat.

Antropologiske studier af kristendom har ofte taget udgangspunkt i spørgsmål om „betydning“ (se fx Geertz 1973). Talal Asad har kritiseret Clifford Geertz' fokus på religion som et symbolsk betydningssystem, der giver mening for den enkelte troende, idet han påpeger, at Geertz' religionsdefinition har sit udspring i kristendommen og derfor er begrænset (Asad 1993:29). Snarere end et spørgsmål om betydning vil jeg rette fokus mod forhandlingen af grænserne for ens liv, og her er antagelsen, at grænsen imellem det offentlige og det private er et skel, der er både politisk og eksistentielt. 
Hvor præsten fra Shuowangkirken valgte meget eksplicit at udfordre rammerne for det tilladte ved at flytte sin prædiken udenfor på en offentlig plads, navigerer de fleste kinesiske kristne i højere grad i forskellige former for gråzoner - og det er ofte ikke helt klart, hvornår de overskrider grænserne i en sådan grad, at deres handlinger får konsekvenser. Den samme følelse af uvished var min faste følgesvend i løbet af feltarbejdet.

\section{Beijings mure}

Dagen efter jeg var ankommet til Beijing i juni 2012, vågnede jeg k1. 5 om morgenen. Solen var ved at stå op som en uklar skive bag et tykt lag af smog. Jeg besluttede mig for at løbe en tur i Solparken, men da jeg kom frem til parken, blev jeg mødt af en tung hængelås. En søvnig vagt fortalte mig, at parken først åbnede kl. 6. Slukøret indså jeg, at jeg måtte nøjes med at løbe en tur rundt om parkens yderside - bogstavelig talt på den forkerte side af muren. Det var et næsten for konkret billede på min situation. Jeg skulle påbegynde mit feltarbejde om populariteten af kinesiske undergrundskirker, ${ }^{3}$ og udfordringen var netop at finde den rette indgang til denne mere eller mindre skjulte undergrundsverden.

Min søgen efter en vej ind i undergrundskirkerne havde karakter af at gå varsomt frem i en tåget dis, hvor jeg gentagne gange pludseligt ramte grænsen, som en fugl, der flyver ind i et vindue. Flere gange udspillede dette scenarie sig. Jeg blev inviteret med til søndagsgudstjeneste i en undergrundskirke, men kort forinden modtog jeg en sms om, at det alligevel ikke gik an, at jeg kom, da jeg var udlænding. Jeg ville selvfølgelig ikke komme et sted, hvor jeg ikke var velkommen, eller hvor nogle følte sig utrygge ved min tilstedeværelse, og jeg overvejede helt at droppe mit forehavende.

Som en slags plaster på såret satte en af mine kontakter mig i forbindelse med hr. Han - en kinesisk samfundsforsker, som var medlem af hendes huskirke. ${ }^{4} \mathrm{Jeg}$ ringede til ham, og han bad mig møde ham næste morgen kl. 10 på sit kontor. På vej derhen tog jeg en taxa, og taxachaufføren fortalte med tyk beijingaccent, at tingene set fra hans perspektiv havde ændret sig til det værre i løbet af de sidste 5-10 år. Da vi kørte forbi diverse afspærrede boligområder med engelske navne som Oakwood, Watercrest og Grand Fortune Garden, talte han om, at alle kun tænkte på penge, og at der efterhånden dårligt var plads til laobaixing ren eller almindelige mennesker. Udtrykket betyder ordret de hundrede gamle navne og refererer til de oprindelige hundrede familier, der boede i hovedstaden inden for bymurene.

Da vi nærmede os universitetsbygningen, der blev bevogtet af militærklædte vagter, og hvor det kinesiske flag var hejst, sagde han dystert, at folk derinde ,ikke 
har rene hjerter“. „Deres hjerter er ikke røde som vores, de er sorte,“" sagde han. Jeg spurgte, hvad han mente, og han svarede, at de taler regeringen efter munden. Taxachaufføren gav altså udtryk for en oplevelse af, at den økonomiske vækst, der har præget Kina og i særdeleshed storbyer som Beijing, er ulige fordelt, og at kommunistpartiet og regeringen ikke har „rene hjerter“ eller ædle hensigter. Som modstykke hertil fremhævede han både Buddha og Jesus som udtryk for en mere autentisk og ægte sfære uden mure eller skel mellem rige og fattige, troende og ikke troende. Grænserne imellem religion og stat er omstridte i Kina. I det følgende vil jeg se nærmere på, hvordan disse grænser er blevet opfattet historisk $i$ en kinesisk kontekst, og hvilke implikationer dette har for nutiden.

\section{Religion, stat og himlens mandat}

En del af nøglen til at forstå det ambivalente forhold imellem religion og stat er ifølge Richard Madsen, at kinesisk folkereligiøsitet siden kejsertiden har indeholdt en spænding imellem to poler shen og ling. Shen forbindes med „himlens mandat“", statens etos om at skabe social harmoni og understøtter altså magthaverne. Ling repræsenterer derimod skyggesiden af shen og knytter sig til folkelig modstand, og den kinesiske historie er fuld af eksempler på dommedagsbevægelser, der har udfordret statens magt. Ifølge Madsen har den kinesiske regering i praksis - om end ikke officielt - opgivet den marxistiske tanke om, at modernisering med tiden vil udviske al religiøsitet, og dermed følger den kinesiske regering i praksis samme politik over for religion, som Ming/Qing-kejserne gjorde. De former for religiøsitet, der anses at være i overensstemmelse med statslige ideer, accepteres, imens andre former for religiøsitet opfattes som en trussel mod staten, der bør bekæmpes (Madsen 2011:81).

I nyere tid har Falun Gong-bevægelsen udfordret dette skel. Vivienne Shue har argumenteret for, at netop fordi bevægelsen mimer staten og forsøger at etablere et moralsk alternativ til staten, blev den set som en trussel (Shue 2004:60-61). Da Falun Gong-udøvere den 4. juni 1999 (på 10-årsdagen for massakren/episoden i 1989) gennemførte en fredelig demonstration uden for regeringskvarteret Zhongnan Hai, ikke langt fra Den Himmelske Freds Plads, gik de over stregen. Den kinesiske regering slog hårdt ned på bevægelsen, der fik den officielle betegnelse en ,ondsindet kult“. Kristne undergrundskirker befinder sig strukturelt set $i$ en lignende position - i skyggesiden af staten.

I et officielt direktiv fra kommunistpartiets centralkomite, som blev lækket til The Washington Post, fremgår det, at ,universiteter ikke må tillade, at udlændinge på nogen som helst vis gør brug af religion til at infiltrere vores campusser" (Philips 2012; min oversættelse). I dokumentet lyder det: „Fremmede fjendtlige 
styrker gør tiltagende brug af religion til at infiltrere Kina og udføre deres vestlige

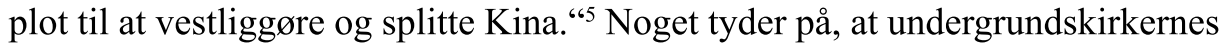
popularitet blandt kinesiske højtuddannede unge med en forkærlighed for vestlige tanker og ideer gør, at de bliver betragtet som en trussel.

Hvor kommunistpartiet oprindeligt definerede sig selv som proletariatets (bøndernes) parti, har det, siden Deng Xiaoping kom til magten og indførte Den Åbne Dørs Politik, gradvist udviklet sig i retning af at blive et eliteparti (Pieke 2009:1). Partimedlemskab er forbundet med en forestilling om en form for ideel personopfattelse, der indebærer et højt uddannelsesmæssigt niveau samtidig med en form for neutral anonymitet, der er forenelig med underkastelse under partiets vilje (ibid.). Samtidig er den kinesiske stat bevidst om det potentielle ideologiske tomrum, kommunistpartiet optræder i, og har igangsat forskellige politiske tiltag under sloganet „et harmonisk samfund“ $i$ et forsøg på at imødegå problemer med et stigende polariseret samfund. De fleste kinesere har dog ikke mærket meget til disse forbedringer (Yan 2009). Metaforen om det harmoniske samfund er en del af regeringens forsøg på at hente moralsk troværdighed, en slags „,himlens mandat", ved en form for genopfindelse af konfucianismen som statsideologi.

\section{Den offentlige og den private sfære}

Det var med en vis nervøsitet, jeg mødtes med min vært hr. Han, da jeg ikke helt kunne gennemskue, hvad hans motiv til at ville mødes med mig var. Vi tog elevatoren i tavshed til 17. sal til hans kontor, der var tæt befolket. Til min lettelse foreslog han, at vi kunne gå en tur i parken lige overfor. „Nogle gange går jeg direkte fra frokost med regeringskadrer videre til møde i min huskirke," sagde han. Han fortalte, at selv ikke hans kolleger kendte til hans huskirkeengagement. „Eller måske ved de det uden at vide det," sagde han.

I samtalen kredsede han om, hvordan han ønskede at udfordre skellet imellem en privat og en offentlig religiøs sfære for at kunne revolutionere samfundet. Han mente, at hvis kristendommen nogensinde skal accepteres i Kina og ikke som nu ses som noget vestligt, må vejen gå via Konfucius. Han forklarede: „Konfucius kan sammenlignes med Johannes Døberen. Han baner vejen for Jesus.“ Hr. Han arbejdede altså i det skjulte på at forbinde konfucianistisk og kristen moral på synkretistisk vis og mente, at det kristne princip om næstekærlighed havde sin pendant i konfucianismen, hvor godhed over for fremmede er en af de højeste dyder. „Det er ikke nok, at de kristne bliver flere og flere, hvis de holder deres tro væk fra den offentlige sfære. Kina har brug for Jesus," sagde han.

Hans forklaring om behovet for ikke blot at leve et dobbeltliv kan måske forstås ved hjælp af Hannah Arendts tese om, at forholdet imellem disse sfærer indebærer 
en politisk spænding. Individuelle tanker og følelser lever en ,skyggefuld tilværelse“, skriver hun, ,medmindre de bliver transformeret til en form, der egner sig til offentlig fremtræden“"(Arendt 1958; min oversættelse). Arendts måde at formulere det på synes at være et godt billede på det stærke ønske om anerkendelse, som hr. Han oplevede i forhold til at legitimere sin tro. Han viste mig nogle publikationer, som han ønskede skulle indføres i det kinesiske skolesystem. Bøgerne omhandlede temaer som det kristne bud om næstekærlighed, men på en indirekte måde. Historier fra Biblen var omskrevet i sekulær form, og han arbejdede sammen med en gruppe ligesindede kristne intellektuelle fra forskellige kinesiske universiteter for, at disse bøger skulle indføres i skolesystemet som et alternativ til det, som han opfattede som partiets propaganda.

Om end hans sprogbrug var langt mere akademisk, havde hans historie en hel del til fælles med taxachaufførens. „Mange mennesker er blevet rige siden reformperioden, men de er ikke lykkelige, fordi de spirituelt set er tomme, “sagde han. Han mente, at kapitalisme og ukontrolleret grådighed har korrumperet den kinesiske moral. Han talte også om nogle episoder, der hen over sommeren havde stor bevågenhed i kinesiske medier, blandt andet om flere trafikuheld, hvor den skyldige part blot efterlod sine ofre på gaden for at undgå at komme til at hænge på en hospitalsregning. ,Folk har brug for andre åndelige værdier for at blive fredfyldte og lykkelige. De har ikke kun brug for penge. De har brug for himlen,“ sagde han og fortalte, at hele hans familie var konverteret til kristendommen, inklusive hans far, som havde været medlem af kommunistpartiet og var blevet omvendt på sit dødsleje. Han mente, at han nu ville kunne møde sin far i himlen, når han selv døde.

Selvom hr. Hans kristne engagement var et intellektuelt projekt, og selvom han talte om at skabe et nyt etos (shen), var der tilsyneladende ikke nogen klar grænse mellem hans politiske projekt om at ændre samfundsmoralen og hans egen eksistentielle situation i form af forholdet til hans far. Som partimedlem var hans far i en vis forstand partiet, og det at have omvendt ham gav håb om også at kunne omvende andre eller ovenikøbet at omvende partiet. Med andre ord, selvom skellet imellem shen og ling $\mathrm{i}$ kinesisk religion giver mening på et strukturelt plan, er de oplevede kategorier langt mere flydende, og hr. Han forsøgte at mestre en hårfin balance mellem på den ene side at ønske at skabe en kristen revolution, mens han på den anden side ikke opfattede sig selv som værende imod regeringen. Han ønskede indirekte at påvirke regeringen og kommunistpartiet i en anden retning uden nogen form for eksplicit politisk konfrontation. Selv beskrev han dog denne position som stærkt ambivalent, fordi han følte, at han var upopulær i begge lejre. „Folk i de officielle kirker kan ikke lide, at jeg kommer i undergrundskirkerne, og folk i undergrundskirkerne ser mig ofte som regeringens forlængede arm, fordi 
jeg også kommer i de officielle kirker og holder møder med regeringskadrer.“ Med andre ord ønskede han at overskride grænserne mellem det offentlige og det private skel på en indirekte måde - ved at omvende sine nærmeste og ved at snige kristent humanistisk tankegods ind i uddannelsessystemet og i akademiske værker for på længere sigt at udviske skellet mellem et undergrundsetos og den dominerende ideologi. ,Jeg er ikke imod regeringen," sagde han mange gange i løbet af vores samtale, samtidig med at han vred sine hænder og fremstod bekymret og nervøs.

Da vi skiltes, inviterede han mig til at komme med til gudstjeneste i sin huskirke. Han ville sende mig en sms med adressen. Jeg fik dog aldrig denne sms og ville ikke trænge mig yderligere på.

\section{Det Nye Træs Kirke}

Endelig lykkedes det en dag at blive inviteret til søndagsgudstjeneste i en protestantisk huskirke, hvis navn kan oversættes til Det Nye Træs Kirke. En af mine bekendte, en underviser ved Beijing Universitetet, satte mig i forbindelse med en af sine kristne studerende. Forventningsfuld fandt jeg frem til en af Beijings største boghandlere, hvor jeg skulle møde Houlin, der studerede engelsk litteratur. Hun talte godt engelsk og virkede helt afslappet og forsikrede mig om, at det ikke var noget problem, at jeg kom med. Alle var velkomne, sagde hun. „I Guds øjne er vi alle søstre og brødre," tilføjede hun. Da jeg spurgte hende, hvor mange kristne, hun mente, der var i Kina, svarede hun, at hun ikke kunne sige det præcist, men: „Jeg tror, vi er flere kristne end medlemmer af partiet.“ Denne formulering hørte jeg gentagne gange. Der er 70 millioner medlemmer af kommunistpartiet. Denne idé siger noget om de unges forestilling om at kunne forandre Kina via kristendom - altså at kristendom udgør et forestillet alternativ til det eksisterende system.

På vejen gik vi forbi Haidiankirken, en stor statsautoriseret kirke. Kirkeklokkerne ringede, og mens jeg kiggede interesseret mod kirkens store hvide cementmure og det store kors over den imposante indgang, hastede hun forbi. Hun betragtede disse kirker som forløjede. „De har de flotte lokaler, men de kristne er ikke rigtige kristne," sagde hun. Jeg spurgte hende, hvad hun mente med det, og hun svarede, at kommunistpartiet kontrollerede indholdet af præsternes taler, og at der var meget lidt kristendom i det. For hende handlede kristendom også om retten til at tænke selv og til at sige sin mening, også når den gik imod partiet.

„Gud giver mig styrken til ikke at lade mig kue,“ forklarede Houlin, da jeg spurgte, om hun ikke var bange for at komme i politiske vanskeligheder. En morgen, da hun kom lidt tidligt til gudstjeneste i Det Nye Træs Kirke, mødte hun to civilklædte betjente ved indgangen. De spurgte hende, hvorfor hun kom i huskir- 
ken frem for en af de officielle kirker, hvortil hun svarede, at en kirke for hende var et sted, hvor kristne samledes. Det var altså en indirekte måde at sige, at hun betragtede de andre som falske kirker under statens kontrol og censur. Jeg spurgte hende, om hun var sikker på, at det var i orden, at jeg mødte op, og hun svarede selvsikkert, at det ikke var noget problem. „Vores kirke er kaifang," sagde hun, det vil sige åben og progressiv.

Som Webb Keane har påpeget, er den postkoloniale verden spækket med eksempler på, at kristendom er blevet uadskillelig fra ideer og praksisser, der forbinder tanker om modernitet med frigørelse (Keane 2007). Flere studier har også beskæftiget sig med konvertering til kristendom som en form for politisk protest blandt asiatiske minoritetsfolk og marginaliserede grupper (se fx Keane 2007; Salemink 2009). I dette kinesiske tilfælde er det dog interessant at bemærke, at der ikke er tale om marginaliserede grupper, der konverterer til kristendom, men tværtimod om Kinas unge urbane elite, i en vis forstand legemliggørelsen af landets fremtid.

Vi gik et par blokke videre, og hun ledte vejen ind i et gråt ubestemmeligt lejlighedskompleks. Vi tog elevatoren op til 12. sal og åbnede døren til et propfyldt lokale, hvor folk sad på stole, der var stillet op på rækker. Lokalet var meget spartansk indrettet med hvide vægge og en slags forhøjet pult som alter. Et par sorte gardiner var trukket for vinduerne ved lokalets endevæg. Flere gav mig hånden og bød mig velkommen på en varm og hjertelig måde, blandt andet præsten, der viste sig at være en kvinde. Seancen startede med, at en ung mand spillede salmer på akustisk guitar, og folk sang salmer på kinesisk. Mange havde tårer i øjnene.

Flere gange i løbet af prædikenen refererede præsten til lukningen af Shouwangkirken og til „deres søstre og brødres skæbne“. Præsten lavede også en allegori over lukningen af denne kirke og uddrivelsen fra Egypten. Dette forhold fik mig til at spekulere på, om statens forsøg på at sætte grænser for de kristne udøvere havde den modsatte effekt. Det virkede, som om det snarere var med til at styrke deres fælles narrativ om at tilhøre det udvalgte folk, der blev uretmæssigt fordrevet eller undertrykt. Samtidig var det bemærkelsesværdigt, at en af de sange, der blev sunget, havde et omkvæd, der lød „Lad Jesus forandre Kina, lad Jesus gribe Kina“.

Den dag blev fem unge mennesker døbt i kirken. Én efter én stod de frem og aflagde vidnesbyrd, som bestod $i$ at fortælle om sine personlige grunde til at vælge Gud og Det Nye Træs Kirkes fællesskab. Deres grunde varierede, men kredsede i flere tilfælde om oplevelser af modgang. Temaer som arbejdsløshed, familiekonflikter, stress og depression gik igen. I flere tilfælde nævnte de, at de havde forældre eller andre slægtninge, som var partimedlemmer, og at de håbede 
på med tiden at kunne omvende dem. Igen syntes der at være en tæt forbindelse mellem deres individuelle biografier og deres forhold til kommunistpartiet.

Det sidste element i seancen indebar, at nyankomne, det vil sige folk, der var i kirken for første gang, blev bedt om at rejse sig op og give sig til kende. Min veninde hviskede til mig, at jeg også skulle sige et par ord. Jeg rejste mig op som den allersidste, sagde meget kort mit navn, forklarede, at jeg var antropolog og i gang med en undersøgelse af kristendom i Beijing og takkede dem for at byde mig velkommen i kirken. Jeg tilføjede, at jeg var rørt over deres åbenhed. Der lød en stor klapsalve, og jeg satte mig ned igen med bankende hjerte. Herefter begyndte folk langsomt at sive ud af lokalet, og på vejen blev jeg budt velkommen af mange, men også udspurgt i en grad, som gjorde mig usikker på, hvor meget jeg burde sige. Det var et vanskeligt dilemma i og med, at jeg på den ene side ønskede åbenhed og ærlighed fra deres side og samtidig dårligt kunne forvente dette, hvis ikke jeg mødte dem med samme åbenhed og ærlighed. Jeg svarede så kort som muligt på deres spørgsmål.

Efter gudstjenesten gik Houlin og en gruppe af unge mennesker ind i et tilstødende lokale i kirken. Det var her, „,ungegruppen“ holdt til, fik jeg forklaret. Rummet var kendetegnet ved en afslappet og jovial stemning. Nogle gjorde klar til korprøve, læste i og talte om Biblen eller tog en lur. Jeg faldt ind og ud af samtaler og søgte tilflugt i min notesbog, imens jeg tænkte over, at denne organisering, hvor unge havde deres rum og de lidt ældre et andet, forekom mig at mime kommunistpartiets måde at organisere sig på. Som tidligere nævnt blev Falun Gong-bevægelsen set som en trussel, fordi den mimede staten og søgte at fremstå som et moralsk alternativ til staten (Shue 2004), og jeg mener, at det er sandsynligt, at det samme gør sig gældende i forholdet mellem den kinesiske stat og undergrundskirkerne. På samme måde, som medlemmer af partiet har til opgave at fremstå som foregangspersoner og bestræbe sig på at fortælle om partiets ideologi (Bregnbæk 2012), havde kirkens ungegruppe den rolle, at de skulle tale med dagens nyankomne og fortælle dem om Biblen, Guds kærlighed og kirkens særlige sammenhold.

\section{Elias}

Et af de unge mennesker, der blev døbt, den første gang jeg var i kirken, var Elias. Han forklarede mig senere, at jeg skulle passe på med at have tillid til alle i kirken. Han mente, at der kunne være civilklædte betjente blandt deltagerne. Det viste sig, at lukningen af Shouwangkirken faktisk var en stor del af grunden til, at han overhovedet var blevet kristen. Han fortalte, at han på daværende tidspunkt var på forretningsrejse som ingeniør på et byggeprojekt i Kazakhstan. 
Det at være uden for Kina havde givet ham en oplevelse af at leve i en boble af løgne, sagde han. På den anden side af ,the great fire wall“", den kinesiske stats censur af internettet, havde han pludselig uhindret adgang til andre historier om den kinesiske virkelighed og historie end dem, han var vokset op med. Da han hørte om lukningen af denne kirke i Beijing, tænkte han, at „,måske er dette sandheden". Han vidste ikke ret meget om kristendom, men følte sig draget af dette alternative fællesskab, der gik imod strømmen. Derfor fandt han frem til kirkens præst, og han fortalte mig med tydelig stolthed, at han havde sendt ham en e-mail. Præsten havde svaret, at hans lejlighed blev overvåget af sikkerhedspolitiet, så han kunne ikke længere praktisere, men han anbefalede kirken ved navn Det Nye Træ. Elias fortalte, at han havde fundet troen på Gud, men også, at han havde fundet et nyt fællesskab. „Regeringen forsøger at kontrollere alt. Det er ligesom George Orwells fremtidsroman, men regeringen kan ikke kontrollere alt," sagde han. „Regeringen er bange for folk, der tænker selv.“

Da jeg spurgte til Elias' familie, sagde han: „Begge mine forældres liv blev smadret af Kulturrevolutionen." Han forklarede, at ingen af dem havde fået en uddannelse, men i stedet var blevet sendt til ,tankereform gennem manuelt arbejde" $i$ et område uden for byen Chengdu i det sydvestlige Kina. De havde tilbragt 5-6 år i området som del af reformen og havde aldrig taget skridtet tilbage til byen. Mens han gav udtryk for en del ømhed over for og identifikation med sin mor, var han vred på sin far, som drak og behandlede moren dårligt. Elias var også raget uklar med sin storesøster på grund af en konflikt i forbindelse med nogle penge, som søsteren havde lånt af ham og aldrig betalt tilbage. Han beskrev hende som egoistisk og egenrådig ligesom faren.

Den samfundsmæssige kritik af korrupte kadrer, grådighed og tomhed havde altså en direkte parallel i hans egne familierelationer. Elias mente, at en revolution måtte finde sted i Kina: „Tingene kan ikke fortsætte sådan her. Det er tydeligt, at kadrer bliver rigere og rigere uden at have noget at have det i. Hvis ikke man er fuldstændig tankeløs, er det umuligt ikke at opdage dette. Uden Gud ville jeg ikke have noget håb."

I sit arbejde om håb tager Ernst Bloch afsæt i den præmis, at længslen efter „det nye“ eller et forestillet alternativ er uløseligt forbundet med en oplevelse af, at „,er mangler noget i vores liv“ (Bloch 1986). Håb og afsavn var for Elias tæt forbundet, og han forsøgte via troen at mobilisere en form for tro på en alternativ fremtid. Dette syntes at indebære en forbindelse til et bredere religiøst fællesskab, der også rakte uden for Kinas grænser. I mine samtaler med ham refererede han ofte til ,vores Gud“, selvom jeg lidt akavet måtte minde ham om, at jeg ikke betragter mig selv som kristen andet end af kultur, men han fastholdt alligevel denne forbindelse. Det var, som om han ønskede at udvide sin tro med henblik på at 
skabe en forbindelse til en global og kosmopolitisk sfære. Hvad angår betydningen af skellet imellem den private og den offentlige sfære eller spørgsmålet om at måtte affinde sig med at begrænse sin tro til en sluttet kreds af ligesindede, der mødes i det skjulte, tilføjede han, at han syntes, at det var et tegn på regeringens illegitime kontrol. „Vi ønsker ikke at skade nogen. Tværtimod,“ sagde han. Og videre: „Udøverne i Shouwangkirken gjorde det rigtige, da de valgte at trodse regeringen og give sig til at holde gudstjenester udenfor. Jeg beundrer dem og ville ønske, at jeg kunne gøre det samme, men det har jeg ikke modet til endnu. Måske kommer det en dag."

Elias konfronterede altså ikke direkte staten med sine holdninger eller sin modstand, ligesom han holdt sin tro skjult for sine forældre og mange af sine nærmeste. I den forstand syntes hans engagement mere at svare til det, Ernst Bloch kalder ,håbets ånd“ - en forhåbning om et andet liv frem for en direkte handling (Jackson 2011:xiii). Elias syntes klar over, at det er farligt at håbe, da det er muligt at blive skuffet. Han beundrede medlemmerne af Shouwangkirkens mod, men ønskede ikke at komme i politiske vanskeligheder og valgte derfor at holde sin tro skjult, selv for sin nærmeste familie.

\section{Nære relationer}

Efter at have været $\mathrm{i}$ ungegruppen en periode begyndte en del af de unge hver søndag at gå til et kursus kaldet „,nære relationer“, og jeg deltog også. Kurset blev holdt af to udøvere fra Det Nye Træs Kirke, men indholdet af kurset var kun indirekte religiøst. Efter en hurtig frokost bestående af fastfoodnudler, som vi købte på vejen, bevægede vi os et par blokke fra kirken og ind i endnu et spartansk indrettet lokale, som var fyldt til bristepunktet af unge mennesker i 20'erne og 30'erne. Nogle kom som par, men størsteparten var single.

Lidt akavet hilste jeg på underviseren, en slank kvinde i 40'erne med elegant opsat hår. Kurset viste sig at være meget lidt eksplicit religiøst, men snarere at være en form for selvudviklingskursus. En del af tiden gik med at se videoforelæsninger af en mandarintalende amerikansk-kinesisk psykolog. De blev projiceret op på endevæggen fra en computer, og folk samlede sig på stole og på gulvet foran for at kunne se. Derudover blev der udført forskellige øvelser og rollespil, der havde at gøre med at bearbejde, reflektere over og diskutere sit forhold til sine forældre og tanker om sit kommende ægteskab. Den bagvedliggende idé var, forklarede underviseren, at det var nødvendigt at bearbejde sin egen familieopvækst for på sigt at kunne indgå i et harmonisk forhold til en kommende mand eller kone. En af øvelserne gik ud på at udøve små rollespil i form af gestaltøvelser, hvor de unge gennemspillede henholdsvis rollen som deres forældre og sig selv. Under 
denne øvelse gav Elias sig til at pille ved sin telefon og fandt tilsyneladende et påskud for at forlade lokalet. Jeg sad ved siden af en ung kvinde, Wang Jing, der også var tavs under øvelsen. Imens vi iagttog, at nogle af de andre gennemførte de små rollespil, lagde jeg mærke til, at de unge talte om deres forældres svigt. Den kristne terminologi om tilgivelse var fremtrædende, og i et samfund, hvor forpligtelsen til at ære og respektere sine forældre er meget stærk (Fong 2004; Kipnis 2009), synes det påfaldende, at flere unge talte om at tilgive deres forældre. Et eksempel på et sådant forsøg på tilgivelse kom fra Wang Jing, der senere fortalte mig sin historie.

\section{Wang Jing}

Da jeg mødte Wang Jing, var hun lige vendt tilbage til Kina efter mange år $\mathrm{i}$ USA. Hun fortalte, at faren forlod familien, da hun var 3 år gammel. Hun var derfor vokset op alene med sin mor, som hun beskrev som en nu cheng ren - et udtryk, der bogstaveligt talt betyder „kvinde stærkt menneske“, og som bruges om kvindelige forretningsfolk, der er blevet rige i reformperioden. Med andre ord var moren blandt dem, der havde fået en universitetsuddannelse, da optagelse på universitetet igen blev muligt, efter at Kulturrevolutionen var afsluttet. Hendes mor havde blandt andet arbejdet i mineindustrien, og i den forbindelse havde hun boet på Palau, en lille ø i Stillehavet. Wang Jing var rejst med moren, men hun fortalte, at hun i den periode havde følt sig meget ensom. Desuden havde der været konflikter mellem dem: „Min mor havde et meget hidsigt temperament, og vi kunne slet ikke kommunikere. Hun slog mig, og jeg hadede hende for det,“” sagde hun. Wang Jing tilføjede, at hun nu kunne se, at moren var under et stort pres som enlig mor med en travl karriere. Derudover havde hun et forhold til en gift mand, som hun håbede ville forlade sin kone. Samtidig følte Wang Jing sig meget udenfor blandt sine klassekammerater. Wang Jing forklarede, at hun altid havde været religiøs. Selv som helt lille havde hun bedt, men hun vidste ikke, hvor hun skulle rette sin tro hen. Hun havde bedt til Buddha, og hun havde bedt til den græske gud Athena i forbindelse med optagelsesprøven til universitetet, men der gik lang tid, før hun fandt den kristne Gud.

Wang Jing ønskede i denne periode at få et stipendium til et amerikansk universitet, og drømmen gik i opfyldelse. Hun tog alene til Wisconsin for at studere, og hun forklarede, at en del af grunden var, at hun så kunne komme væk fra sin mor. Wang Jing beskrev, hvordan hun gradvist blev del af en amerikansk adventistkirke. Fra indledningsvis at have været skeptisk befandt hun sig en dag til gudstjeneste, hvor hun ,blev rørt af Helligånden“. Hun forklarede, at hun havde grædt længe foran forsamlingen, og at hun ikke før havde givet udtryk for sine 
følelser offentligt. Men det var ifølge hende selv en stor lettelse, og fra den dag havde hun troet på den kristne Gud.

Hun blev derefter i USA - blandt andet for at være på afstand af sine forældre - og havde kun besøgt moren sjældent. Men for to år siden mistede Wang Jing sit job på grund af finanskrisen, og hun så sig nødsaget til at rejse tilbage til Kina. „I starten bebrejdede jeg Gud,“ sagde hun. „Hvorfor skulle jeg rejse tilbage til Kina?" Men hun mente, at det var sket, fordi det var meningen, at hun skulle forsone sig med sin familie, og hun arbejdede nu på at kunne tilgive sine forældre. Hun havde selv taget initiativ til at mødes med sin far og var kommet tættere på at tilgive ham. Hendes forhold til moren var også blevet bedre. „Før var jeg konstant plaget af dårlige tanker om min mor og min far, om deres synd og svigt, men jeg forsøger at give slip. Gud hjælper mig med at tilgive, jeg kunne ikke gøre det uden min tro.“

Ifølge Hannah Arendt er tilgivelse en form for accept af det, der ikke kan ændres - en given slip. Tilgivelse handler hverken om at elske dem, der har begået en uret, eller om at forstå dem. Det er snarere en form for forløsning, hvorigennem man gør krav på sit eget liv og frigør sig fra det tag, en uretfærdig anden har haft på én eksempelvis i form af tanker om hævn (Jackson 2012:213-14). For ikke at være bundet til de negative følelser ønskede Wang Jing at frigøre sig fra dem og dermed ændre sin oplevelse af at være i verden. Frem for at kæmpe mod en fortid, hun ikke kunne ændre, forsøgte hun snarere at give slip.

På spørgsmålet om, hvorvidt hun delte Elias’ revolutionære drømme, trak hun lidt på skuldrene. „Hvad kan vi gøre?“" sagde hun og henviste til, at 1989episoden havde haft den effekt, at få intellektuelle gjorde direkte oprør, om end enkelte kritiske stemmer florerer på weibo, den kinesiske udgave af Facebook/ twitter. Hun viste mig blandt andet et opslag, hvori moderlandet Kina omtaltes som en stedmor, der ikke længere elskede sine børn. I kontrast til staten, som hun omtalte som en ubarmhjertig forælder - en stedmor, fastslog hun, at Gud elsker alle sine børn, selvom de begår fejl. Hun havde altså vendt staten ryggen, og hun var ikke bange for at komme i karambolage med myndighederne, men mente ikke, at det var muligt at ændre det politiske system. Hendes udtalelse kan ses som en accept af, at livet leves inden for visse grænser, og at i Kina er det politiske systems grænser noget, man må leve med. Som hun sagde: „Men regeringen kan ikke kontrollere mine tanker.“

\section{Overskridelse eller accept af tilværelsens begrænsninger?}

I denne artikel har jeg forsøgt at reflektere over forholdet mellem det givne og det foranderlige som en intersubjektiv balance, der håndteres og opleves forskelligt, 
alt efter øjnene der ser. De unge kristne kinesere, som jeg mødte i Beijing, syntes alle at være på jagt efter et eller andet. De ønskede forandring $-i$ forhold til deres eget liv og de sociale relationer, de befandt sig i, og/eller politisk forandring på Kinas vegne. Ifølge antropologen Michael Jackson lever alle mennesker deres liv inden for visse grænser, selvom grænserne er meget forskellige (Jackson 2011: xi). I bogen Life Within Limits: Well-being in a World of Want (2011) ser Michael Jackson lykke som uløseligt forbundet med vores intersubjektive balance mellem at handle i verden og være genstand for andres handlinger. Han argumenterer dog også for, at det ikke entydigt kan afgøres, i hvilken udstrækning lykke kommer af at acceptere livet, som det leves inden for de givne grænser, og i hvilken udstrækning lykke kommer af at forsøge at overskride og ændre disse grænser eller livsbetingelser.

De personer, hvis historier og forhåbninger jeg har genfortalt her, kredser på forskellig vis om en form for afvejning af grænserne for det mulige i forhold til at ændre de eksisterende rammer for deres liv. Hr. Han lod til indirekte at udfordre skellet mellem på den ene side de officielle kirker og kommunistpartiets officielle etos og huskirkernes afgrænsning til en privat og skyggefuld tilværelse på den anden side. Elias fantaserede om en revolution, der kunne afsætte, hvad han opfattede som Kinas korrupte ledere, og ønskede at krydse denne grænse mere eksplicit. I praksis holdt han dog sin tro skjult for ikke at komme i vanskeligheder og trak sig dermed væk fra den offentlige sfære og vendte sig indad mod en kreds af ligesindede. Han søgte en form for håb om en anderledes fremtid - både på det individuelle og det samfundsmæssige plan - om end det forblev et ønske og en uopnåelig drøm. I praksis holdt Elias sin tro skjult for sine forældre på samme måde, som han holdt den skjult for sin arbejdsgiver og i forlængelse heraf for den kinesiske stat. Flere unge ønskede som hr. Han at omvende deres forældre, og jeg stødte gentagne gange i løbet af feltarbejdet på eksempler på, at dette rent faktisk lykkedes. Selvom undergrundskirker er i statens søgelys, tolereres de i vid udstrækning, så længe udøverne ikke overskrider grænsen mellem den private og offentlige sfære. Måske giver det mening at sige, at udøverne ændrede deres oplevelse af at være i verden ved at overskride rammerne for det tilladte og derigennem at generere en form for håb - selvom de ikke var i stand til direkte at ændre de eksisterende politiske strukturer.

På den anden side kan man ikke vide, hvilken betydning en samling af alternativt tænkende mennesker kan få på længere sigt. „Lad Gud forandre Kina, lad Gud gribe Kina“" synger de og erklærer sig dermed som medlemmer af et alternativt fællesskab, der godt nok holder sig skjult bag lukkede mure og i en vis forstand vender sig indad og er optaget af deres egne nære relationer. Men hvis vi ser på de dommedagsbevægelser, som den kinesiske historie er fuld af, og som også 
Shouwangkirken minder os om, rummer disse måske også potentialet til at blive noget andet og større.

\section{Noter}

1. I Kina findes der både protestantiske kristne (jidujiao, der bogstaveligt betyder Jesu lære eller xin jiao, der betyder ,nye lære"), katolikker (tianzhujiao, der betyder ,himlens herskers lære“) og et mindre antal ortodokse kristne (Bautista \& Lim 2009).

2. For et mere nuanceret billede af disse tal viser en opgørelse fra The Information Council of the State Council, at der findes 100 millioner religiøse udøvere i Kina. Inden for protestantismen er der 12.000 kirker, 25.000 mødesteder, 18.000 gejstlige og 10 millioner troende. Inden for katolicismen er der 4.000 kirker, 4.000 gejstlige og 4 millioner troende (citeret i Ashiwa \& Wang 2011).

3. Denne artikel er baseret på 3 måneders feltarbejde i Beijing i 2012 som del af mit postdocprojekt „An Exploration of the Religious Lives of Chinese Urban Youth“ finansieret af Det Frie Forskningsråd (FKK).

4. For at beskytte mine informanters anonymitet er alle navne pseudonymer.

5. Dette dokument blev lækket nogle måneder efter, jeg havde afsluttet mit feltarbejde, og giver et indtryk af, at konflikten imellem huskirker og den kinesiske stat synes at optrappes.

Søgeord: Kina, ungdom, kristendom, håb, grænser, statskontrol, huskirker

\section{Litteratur}

Aikman, David

2003 Jesus in Beijing: How Christianity is Challenging the Global Balance of Power. Washington DC: Regnery Publishing.

Arendt, Hannah

1958 The Human Condition. Chicago: Chicago University Press.

Asad, Talal

1993 Genealogies of Religion: Discipline and Reason of Power in Christianity and Islam. Baltimore: John Hopkins University Press.

Ashiwa, Yoshiko \& David L. Wank (eds)

2009 Making Religion, Making the State. Stanford: Stanford University Press.

Bautista, Julius \& Francis Khek Gee Lim (eds)

2009 Christianity and the State in Asia: Complicity and Conflict. Routledge Studies in Asian Religion and Philosophy. New York: Routledge.

Bloch, Ernst

1986 The Principle of Hope. Cambridge, MA: MIT Press.

Bregnbæk, Susanne

2012 Between Parents, Party and Peers: The Quandaries of Young Chinese Party Members in Beijing. Third World Quarterly 33(4):721-35. 
Fong, Vanessa

2004 Only Hope: Coming of Age under China's One Child Policy. Stanford: Stanford University Press.

Geertz, Clifford

1973 Religion as a Cultural System. In: C. Geertz: The Interpretation of Cultures. Pp. 87-125. New York: Basic Books.

Jackson, Michael

2011 Life Within Limits: Well-being in a World of Want. Durham \& London: Duke University Press.

2012 Lifeworlds: Essays in Existential Anthropology. Chicago: Chicago University Press.

Keane, Webb

2007 Christian Moderns: Freedom and Fetish in the Mission Encounter. Berkeley: University of California Press.

Kipnis, Andrew

2009 Education and the Governing of Child-centered Relatedness. In: S. Brandtstädter \& G.D. Santos (eds): Chinese Kinship: Contemporary Anthropological

Perspectives. Pp. 204-22. London: Routledge.

Lozada, Eriberto P., Jr.

2001 God above Ground: Catholic Church, Postsocialist State, and Transnational Processes in a Chinese Village. Stanford: Stanford University Press.

Madsen, Richard

1998 China's Catholics: Tragedy and Hope in an Emerging Civil Society. Berkeley:

California University Press.

2011 Religious Renaissance in China Today. Journal of Current Chinese Affairs 40(2): 17-42.

Pieke, Frank N.

2009 The Good Communist: Elite Training and State Building in Today's China.

Cambridge: Cambridge University Press.

Philips, Tom

2012 Chinese Universities Urged to Fight Back against Foreign Religion. 19. december. www.telegraph.co.uk.

Salemink, Oskar

2009 Is Protestant Conversion a Form of Protest? Urban and Upland Protestants in Southeast Asia. In: J. Bautista \& F.K.G. Lim (eds): Christianity and the State in Asia: Complicity and Conflict. Pp. 36-59. New York: Routledge.

Scott, Janet Lee

2007 For Gods, Ghosts and Ancestors: The Chinese Tradition of Paper Offerings. Seattle: University of Washington Press.

Shue, Vivienne

2004 Legitimacy Crisis in China? In: P.H. Gries \& S. Rosen (eds): State and the Society in the $21^{\text {st }}$ Century China: Crisis, Contention and Legitimation. Pp. 59-83. London: Routledge. 
Vala, Carsten T.

Pathways to the Pulpit: Leadership Training in "Patriotic" and Unregistered

Chinese Protestant Churches. In: Y. Ashiwa \& D.L. Wank (eds): Making Religion,

Making the State. Pp. 96-125. Stanford: Stanford University Press.

Yan, Yunxiang

2009 The Individualization of Chinese Society. Oxford: Berg.

Yang, Mayfair

2008 Chinese Religiosities: Afflictions of Modernity and State Formation. Berkeley:

University of California Press. 
